Fecha de recepción: julio 2014

Fecha de aceptación: marzo 2015

Versión final: julio 2015

\section{Building best practices for fashion design pedagogy: meaning, preparation, and impact}

Steven Faerm *

Summary: Historically, universities have adopted a "sink or swim" approach with their hiring of art and design faculty. After years of professional experience, these new faculty enter classrooms without pedagogical training and are expected to succeed as educators. However, designing product and educating students require significantly different skillsets. Additionally, faculty challenges are radically increased due to the seismic changes occurring in design education, the evolving student generation, and the increasingly volatile professional world for which students must be trained. Through trial and error, new faculty often rely on outdated teaching methods used during their own undergraduate experiences. This lack of faculty preparation negatively impacts programs, the graduates' preparation, and ultimately our design industries. This article will discuss the critical need for tomorrow's art and design faculty to acquire -and master- solid pedagogical skills if they are to successfully educate and train future designers. This study aims to provide fashion design educators and program directors with awareness for the importance of providing pedagogy support for new faculty in order to strengthen the students' learning.

Key words: design education - design pedagogy - student development - teaching - fashion design - fashion industry - Parsons - faculty - higher education.

[Summaries in spanish and portuguese at pages 212-213]

(*) Associate Professor, The School of Fashion, Parsons The New School for Design.

\title{
Introduction
}

Historically, universities have adopted a "sink or swim" approach with their hiring of fashion design faculty. After years of professional experience, these new faculty enter classrooms without pedagogical training and are expected to succeed as educators. However, designing apparel and educating students require significantly different skill-sets. The faculty's challenges are increased due to the seismic shifts occurring in American fashion design education, the rapidly evolving student generation, and the increasingly volatile professional world for which students must be trained. The lack of 
faculty's pedagogical preparation negatively impacts the program, graduates' academic preparation, and ultimately the fashion design professional practice and industry.

The need for faculty to acquire advanced fashion design pedagogy skills is particularly dire due to shifting global economies. Increasingly, traditional fashion centers such as New York City's Garment Center, are uprooting their production facilities to less expensive facilities in China, India, and other nations. When the design process no longer shares close adjacencies to the garment making, questions around the future designer's role in local and global economies surface. To successfully prepare and evolve their roles, fashion design must adopt larger, broader "lenses" through which the larger systems is viewed. Furthermore, fashion designers must remain cognizant of the "hows" and the "whys" for these micro- and macro-economic changes. In his book A Whole New Mind: Why Right Brainers Will Rule the Future (2005) author Daniel Pink describes the reason for adopting this broader and more contextual role by stating:

We are moving from an economy and a society build on the logical, linear, computer-like capabilities of the Information Age to an economy and a society built on the inventive, empathic, big-picture capabilities of what's rising in its place, the Conceptual Age. (p. 1-2)

Many researchers speculate the U.S. workforce and economy will move into areas that are increasingly knowledge based, while those jobs emphasizing rote-skills will be outsourced to other nations, thus allowing U.S. companies to pay lower wages overseas. For example, the chief executive of GE India told London's Financial Times that: "Any job that is Englishbased in markets such as the U.S., the U.K., and Australia can be done in India. The only limit is your imagination" (Merchant, 2003). Forrester Research asserts at least 3.3 million white-collar jobs and $\$ 136$ billion in wages will shift from the U.S. to low-cost countries like India, China, and Russia by 2015 (Pink, 2005, p. 38). To prepare graduates for this new professional landscape, fashion design education is undergoing a seismic overhaul.

Design and design education are intricately linked; it is impossible to assess the state of the design profession without thinking about how one becomes a good designer (Wolff \& Rhee, 2009). The long-held academic philosophies rooted in the Bauhaus ideologies of "making" that have been widely adopted by American design schools are being eclipsed by broader interdisciplinary and theory-centric models. The new curricula aims to equip students with highly contextual and innovative cross-disciplinary engagement. Through this broader academic approach, design students will become highly adaptable and able to succeed in the increasingly accelerated and knowledge based professional practice.

The unprecedented speed of the fashion industry is evidenced by the rates of apparel production and subsequent excessive consumption. The apparel marketplace has become over-saturated with offerings, and this is altering consumer psychology. As described by Maslow's "Hierarchy of Needs," today's fashion consumers have their primary needs met and are now seeking other forms of (non-physical) stimulation. Consumers no longer demand mere "product," but something that provokes far deeper emotional meaning and resonance. The future role of the designer, then, will be to not simply create aesthetically appealing objects, but to develop complex narratives through the fashion design process in 
order to capture the overwhelmed audience (Pink, 2005). Designers are creative innovators who "bridge the chasm between thinking and doing because they are passionately committed to the goal of a better life and a better world around them" (Brown, 2009). In the process, design will elevate itself to help make our societies healthier, our businesses more profitable, and our own lives richer and more meaningful. (Brown, 2009)

The changing industry and designer's role become more salient when considering how stagnant the evolution of American fashion design education has been since its inception. The call for a radically new framework of design education that focuses on theory, design methodologies, and interdisciplinary engagement is startling since, with the advent of programs and the adoption of Bauhaus principles, fashion design education has gone relatively unchanged. The future classroom will require faculty -largely trained as practitioners- to adopt advanced pedagogy skills and deeper awareness for student development.

Unfortunately, this level of pedagogical preparation is relatively underdeveloped in art and design higher education. Yet not all educational sectors are deficient in providing faculty with substantial preparation and training. Historically, the pre-college levels have placed a significant emphasis on both faculty's understanding of course content and well developed teaching skills. High investment in teacher training leads to astonishing student success, evidenced in such nations as Finland and Singapore. What forms of pedagogical training exists for these faculty? What benefits and successes have resulted from these forms? How can faculty in art and design higher education become better prepared through these methods?

This article will discuss the critical need for tomorrow's art and design faculty to acquire -and master-solid pedagogical skills if they are to successfully educate and prepare future designers. By examining the increasingly complex professional practice, current fashion design education in the U.S., and the future of fashion design education, the need for fashion design faculty to acquire advanced pedagogy will be shown. The broad benefits of providing faculty with advanced pedagogical training are contextualized through three leading nations. This study aims to provide fashion design educators and program directors with awareness for the importance of providing pedagogy support for new faculty in order to strengthen the students' learning.

\section{An increasingly complex future professional practice}

The world is becoming closer as Tom Friedman, a columnist for The New York Times put in the title of his book The World is Flat (2005). Globalization is changing everything and anything our contemporary societies do; how we conduct business, how we communicate, how we form relationships, and ultimately how we live have been impacted by our societies becoming "closer" through technology. These new contexts enable business practices to engage a broader marketplace through production and distribution, and enter locations that were once inaccessible or undervalued.

This newly expanded access has given business owners a seemingly unlimited platform for producing their goods around the world. The subsequent search for less expensive 
production centers has led to the dislocation of traditional centers of apparel production, such as the tailoring and knitwear centers of Italy and New York City's once-prosperous Garment Center. The Garment Center was once the single biggest employer in New York City (Pinkerson \& Levin, 2009) and, as late as 1965, produced 95\% of American clothing (Pinkerson \& Levin, 2009). As manufacturing began to move overseas in the late 1960s, the entire structure of the U.S. apparel industry changed and impacted local factories. Linda Darling-Hammond (2010) underscores the transformed U.S. economy by stating:

Whereas in 1967 more than half (54\%) of the country' economic output was in the production of materials goods and delivery of material services (such as transportation, construction, and retailing), by 1997, nearly two-thirds $(67 \%)$ was in the production of information products (e.g. computers, books, television, and software) and the provision of information services (e.g. telecommunications, financial services, and education). Information services alone grew from about $1 / 3$ to more than half the economy during that 30-year period. (p. 4)

The result on the American apparel production industry was devastating; in 2009, just 5\% of American clothing was made in the U.S. (Pinkerson \& Levin, 2009).

While apparel production has radically declined in the U.S., New York City continues to have a thriving fashion industry. According to the New York City Economic Development Corporation, there are approximately 165,000 people employed in the New York fashion industry, accounting for $5.5 \%$ of the city's workforce (The Municipal Art Society of New York [MASNY], 2011). There are over 900 fashion companies that collectively generate approximately $\$ 9$ billion in total wages (MASNY, 2011). For some of these companies, the semi-annual event of New York Fashion Week provides them with international exposure that attracts visitors who spend nearly $\$ 466$ million each year, thus contributing to the approximately $\$ 773$ million generated per year (MASNY, 2011). The fashion industry contributes to the city's economy by fueling other industries such as marketing, merchandising, finance, advertising, photography, modeling, higher education, theater, and tourism. The financial gains of these practices contribute to the estimated $\$ 55.6$ billion in total sales each year from wholesale, manufacturing, and fashion retail (MASNY, 2011). New York City's fashion industry has grown not only economically, but also through the national (and international) cultural fascination with the fashion industry, designers' lifestyles, and design practice. The release of the documentary Unzipped (1994) that showcased fashion designer Isaac Mizrahi creating a fashion collection from sketch-torunway unleashed a plethora of diverse media outlets. These have ranged from syndicated programs that show designers competing in design prompts each episode (Project Runway), film documentaries that showcase the rarified world of fashion publishing (The September Issue), fictitious dramas that caricature the fashion industry (The Devil Wears Prada), and historical bio-pics that romanticize the lives of famous fashion designers (Coco Before Chanel).

The growing obsession with fashion, promoted and sustained through pop culture, is also seen at mass-retail. Companies, such as Target, Hennitz \& Mauritz (H\&M), and Kohl's, 
invite top-designers that include Karl Largerfeld, Vera Wang, Isaac Mizrahi, and Comme des Garcons to create "guest star" pop-up collections that are met with strong reception (Pink, 2005). One notable example is the Missoni for Target collection that was launched in September of 2011. While the Italian design house's offerings can sell up to $\$ 12,000$, the pieces at Target were mostly under $\$ 40$. This partnership created tremendous, unexpected demand from consumers; when the collection became available online at 6:00 a.m., the company's website crashed by 7:47 a.m. due to high online traffic (Clifford, 2011). The retail stores were faced with identical demand, and led some shoppers to sell highlysought after merchandise on eBay at inflated prices.

\section{Overconsumption}

The combination of increased demands for fashion with the decreased costs of apparel produced overseas is placing consumption at an all-time high. In order to meet demand, mass retailers such as H\&M have reduced their lead times design-to-retail to just three weeks and manage to sell more than 500 million items every year from 1,700 stores (Siegel, 2011; Leonard, 2011). The Spanish retailer Zara has over 200 designers who create 40,000 styles each year, of which 12,000 are produced (Siegel, 2011). The demands for clothing have quadrupled since 1980 (Siegel, 2011). These demands and cycles wreak havoc on our planet. For example, though it takes up just $2.5 \%$ of the world's croplands, cotton production uses $10 \%$ of the world's fertilizers and $25 \%$ of its insecticides (Leonard, 2010). An estimated 13.1 million tons of textiles were generated in 2010, of which the average American household discarded 1.3 pounds every week (Leonard, 2010).

The accelerated output of apparel and heightened levels of consumption are creating an over-abundance in most American urban areas. This seemingly endless stream of supply and choice is changing how consumers relate to design. Daniel Pink (2005) describes the shifting behavior by stating:
Abundance has satisfied, and even over-satisfied, the material needs of millions -boosting the significance of beauty and emotion and accelerating individuals' search for meaning. As more of our basic needs are met, we increasingly expect sophisticated experiences that are emotionally satisfying and meaningful. These experiences will not be simple products. They will be complex combinations of products, services, spaces, and information. They will be the ways we get educated, the ways we are entertained, the ways we stay healthy, the ways we share and communicate. Design thinking is a tool for imagining these experiences as well as giving them a desirable form. (p. 46)

The role of the future fashion designer, then, is not merely one of "aesthetic provider" but as a practitioner who approaches the design process with deeper levels of empathy, sociological pattern-recognition, innovation, and big-picture capabilities. Abundance has made businesses realize that "the only way to differentiate their goods and services 
in today's over-stocked marketplace is to make their offerings physically beautiful and emotionally compelling (Pink, 2005, p. 55). In order for designers to adopt this increasingly complex and sensitive role, they will need to synthesize craft and garment making with scientific knowledge about people, culture, information, and society. The fashion designer must therefore become familiarized with the research methodologies used in the social sciences so they can discover similar, successful research data that inform design processes. This importance for designers to acquire deeper forms of research becomes more meaningful when considering the exorbitant costs needed to build and sustain a brand today; the steep financial investment leaves little room for missteps in the design process. Expenditures can include staging runway shows in New York City that cost between $\$ 150,000$ and $\$ 175,000$ each, placing a one-time advertisement in Vogue that can cost as much as $\$ 173,000$, garment production and shipping, public relations, website development, and broader overhead costs (Fry, Faerm, \& Arakji, 2013; Vogue, 2013).

If brands are to sustain themselves financially in the broadening global marketplace, they can no longer continue such economic gambling by developing collections that are based merely on aesthetic preferences. Rather, through diligent research in consumer behavior and the cultural zeitgeist, designers will be expected to defend their fashion proposals before investing heavily in garment development, fashion shows, production, advertising campaigns, marketing, and distribution. To continue such high levels of risk -and fail just one season-could result in bankruptcy and business closure.

And yet, while the fashion industry is becoming increasingly complex and the need for informed design research is increasing, so is the uncertainty of how the industry will advance. Knowledge is expanding at a breathtaking pace: In the three years from 1999 to 2002, the amount of new information produced nearly equaled the amount produced in the entire history of the world previously (Varian \& Lyman, 2003). The amount of new technical information is doubling every two years (Jukes \& McCain, 2002). Executive Dean of Parsons Joel Towers underscores this uncertainty by stating "we are training students for (situations in which) we don't quite know what the needed skills will be" (Wolff \& Rhee, 2009, p. 9). The accelerated and hyper-globalized fashion industry, the need for sustainable solutions due to over-consumption and production, the changing role of the fashion designer, and the rapid creation of new knowledge that will permeate the design industries calls for a radical shift in American fashion design education and highly trained faculty.

\section{Contemporary fashion design education practices}

Formal, degree-conferring studies in fashion design are a relatively recent development in America. Prior to the 1930s, art and design studies were situated in the school of arts and crafts. The movement, begun through the writings of Carlyle and John Ruskin, but became practice through William Morris, was a direct reaction against industrialization and the excessive ornamentation characteristic of the Victorian era (Elfland, 1990). The movement's doctrine believed: 
The industrial system had to be abandoned and the guild system of manufacture and education had to be restored. If apprentices were educated by masters, then the design of crafts would be an integral part of the training process and design education would be a natural outgrowth of mastery of craft. (Elfand, 1990, p. 152).

Handmade crafts soon became highly fashionable objects for the wealthy and were exemplified through the early architecture of Frank Lloyd Wright, furniture by Gustav Stickley, and Newcomb pottery. As the movement spread, its principles were adopted in most art schools geared to the education of artisans (Crane, 1951).

The shift from the arts and crafts school occurred in the first half of the $20^{\text {th }}$ century with the creation of the German state school The Bauhaus (1919-1933); the school's model strongly influenced the primary structure for art and design higher education, particularly in America (Marshall, 2009). The Bauhaus's mission was to promote "the integration of artistic and practical pedagogy, aesthetics and applied skills to produce artists and designers who can participate as creative individuals in the professional working world, becoming part of society and contributing as a group to the greater good of Germany". (Wax, 2010, p. 23)

As duplicated by many of America's leading fashion design programs, Bauhaus students were encouraged to learn design principles "by doing and making," and studied various art and design fundamentals before progressing to their chosen design specialization such as fashion design, architecture, or graphic design (Marshall, 2009). In order to provide this vocationally based education, faculty were active, practicing artists and designers who imparted their expertise by placing emphasis on how things were made in the contemporary practice (Wax, 2010).

For many American design schools, such as Parsons The New School for Design, the academic mission was originally aligned with The Bauhaus and based on the a tradeoriented activity driven by industry (Wolff \& Rhee, 2009). Other leading institutions, such as The Fashion Institute of Technology (FIT), were launched with government support to supply the growing post-war American apparel industry's need for highly qualified labor (MASNY, 2011). These institutions' fashion design programs taught students practical skills and creativity that prepared them for direct entry into the industry situated along New York's iconic 7th Avenue. Illustrious Parsons graduates including Claire McCardell, Donald Brooks, Bill Blass, Donna Karan, Isaac Mizrahi, and Marc Jacobs helped define American fashion design globally. Others, including Jack McCollough and Lazzaro Hernandez of Proenza Schouler, Derek Lam, Alexander Wang, Jenna Lyons of J. Crew, and Narcisco Rodriguez continue to contextualize the future of American fashion.

Today, fashion design program structures vary across American design schools; students either enter a four year fashion design program directly or are required to complete a "Foundation Year," where they learn the fundamental skills and principles of general art and design before entering three years of dedicated fashion design studies. Upon entering the major, emphasis is placed on building the practical skills associated with the practice, such as pattern making, garment construction, designing fashion "collections," and understanding the various markets. Advanced semesters challenge students to refine their 
design processes and aesthetics through a balanced theory -and skill- based curricula. To augment the academic experience, some programs engage professional brands or visiting designer critics to work with the students on designated projects; while these experiences complement the contextual learning outcomes, they also offer important insights into the professional experience.

Fashion design curriculum is typically framed by the core studio courses of fashion design and garment construction that are taught throughout the undergraduate levels; these are supported by required liberal studies and discipline-related subjects such as digital design, textiles, drawing, business, knitwear, and other courses that support students' individual goals. Semester-abroad programs allow students to engage in other forms of design pedagogy and foreign fashion industries. The capstone experience of the undergraduate education is the development of a graduate portfolio and fashion collection that showcases the student's abilities and launches them into the industry as Assistant Designers. For some, graduate studies in such areas as business, fashion history, and fashion design are undertaken in order to advance professionally or to enter a related area of greater interest. The emphasis of American fashion design education has been largely vocational whereby students are given the skillsets required by the industry. Rather than speculating on how education can innovate and strengthen the industry, academic programs deliver curricula that teaches students what the industry requires of them as emerging young Assistant Designers. This is exemplified by FIT that was started in response to the apparel industry's need for skilled laborers. During WWII, New York City enlarged its apparel production to meet national demand when Parisian houses were temporarily shuttered. The institute opened in 1944 and quickly established a close relationship with industry professionals who frequently gave financial donations to support the burgeoning school. During the 1970s, representatives and industry supporters lobbied to offer bachelors and master's degrees -something that was unheard of at the time for a community college. In 1975, an amendment to the Education Law of New York State permitted FIT to offer BS and BFA programs, and in 1979 its master's programs were authorized. (Bard, 1974)

While the establishment of FIT exemplifies America's historical roots in vocational and practical applications of fashion design education, British fashion design education developed a more scholarly and research-based approach. Schools such as Central Saint Martin's, Royal College of Art, and The London College of Fashion have based their research traditions on humanistic studies and a cultural historical approach "where fashion is considered a cultural phenomenon in a social and historical context" (Skjold, 2008, p. 51). This emphasis began with the development of the 1960 National Advisory Council on Art Education Report, better known as the Coldstream Report, that required the teaching of art and design history -and subsequently art and design theory- to enrich students' overall academic and creative development. The new academic direction led to the replacement of the more vocational Diploma in Design with a new Diploma in Art and Design. Today, the nation's advancement of scholarly fashion studies are reflected in the number of graduate -and doctoral- level programs offered across the U.K.; The London College of Fashion (as of report) offers over twenty-five graduate and postgraduate programs in fashion-related studies. 
Despite this new scholarly emphasis on historical, cultural, and contextual studies that are situated within fashion design programs, many agree that fashion design education is relatively under-theorized when compared to other art and design disciplines such as architecture, fine arts, and industrial design (Skjold, 2008, p. 12). This provides fashion design educators a remarkable opportunity to develop the necessary structures to build and support scholarly activity that enriches students' learning, prepares graduates fully, and innovates industry systems.

\section{The future of design education}

The seismic shifts occurring in our globalized information-based economy are forcing changes in the design profession. This changing professional landscape is intricately linked to design education; it is impossible to assess the state of the design profession and plan strategically- without thinking about how one becomes a good designer (Wolff $\&$ Rhee, 2009). To prepare graduates for successful entry into the field, a very high quantity of fashion design programs in higher education are adopting new academic programs and curricula. The need for new academic models is dire since "....life and work in the global knowledge economy demands more education than has ever been required in human history" (Friedman, 2003).

Comprehending the complexity of this new economy will be critical for teachers of art and design if they are to develop future programs that produce graduates desired by industry; design higher-education will require programs to place design in the context of this knowledge-based economy (Friedman, 2003). How does this "knowledge economy" apply to the fashion design practice? How can faculty, students, and designers prepare for this new era and associated role? Lydia Matthews, Professor of Visual Culture at Parsons, advocates for a higher level of awareness across disciplines. She states:

Artists and designers recognize that they need to have an understanding of world systems, whether they're economic, social, ethnographic, or cultural. At the same time, social scientists and business entrepreneurs are beginning to understand that the systems they work with are in fact designed and that there's a fundamental need to communicate visually and materially across cultures and in a globalized condition. So design skills are being valued in a way that hasn't historically been the case. (Agid, 2008, p. 13)

To prepare their future graduates, many design schools are moving away from teaching to the mere 'artifact', into pedagogy that increasingly emphasizes the design process, the interrelationships between creator and audience, and the role of (often implicit) rules and boundaries (Williams \& Askland, 2011). This need to understand design's interconnectivity is one aim of The Coldstream Report that added historical and contextual studies; these studies "play a valuable role in introducing alternative perspectives to studio work and by encouraging students to analyze and examine the context of their practice, rather than merely "solve problems" (Clark, 1991). This is a more contextualist approach as it 
considers the interactive engagement between the individual and the social environment. The New Design Education, then, is one that encourages and facilitates partnerships between design and the social sciences. After all, design is, on many levels, a service to society and end-users.

The adoption of new pedagogical methodologies that are intertwined with the social sciences will underscore the notion that fashion design:

...is no longer just a vocational, trade-oriented activity (...) but rather a methodology with potential application to almost any kind of problem -the focus has shifted from object to process or system. And design school isn't just for art students anymore. Design education now fosters design thinkers as well as makers -those who know when and how to acquire the knowledge they will need to confront increasingly complex conditions.

(Wolff \& Rhee, 2009, p. 10)

The increasing complexity the future designer will encounter when developing creative proposals will require greater breadth -and depth- of knowledge. The ability to engage with multiple disciplines, and in design teams containing participants with highly diverse expertise, will provide fashion designers with a broader spectrum for creative opportunities. The collective and collaborative variety of experience and background will foster the ability to make big leaps of thought and innovation. (Pink, 2005)

The movement towards developing higher education programs that promote interdisciplinary, multidisciplinary, and trans-disciplinary engagement is growing so significantly that some institutions are adopting the approach to become the defining logic of the whole institution (Marshall, 2009). This form of teaching and learning strengthens students' ability to "integrate ideas and collaborate with people, resourcefulness, lateral thinking" (Wolff \& Rhee, 2009, p. 13). Designer Clement Mok describes the necessity of this academic shift by stating:

The next 10 years will require people to think and work across boundaries into new zones that are totally different from their areas of expertise. They will not only have to cross those boundaries, but they will also have to identify opportunities and make connections between them". (Pink, 2005, p. 135)

Acquiring lateral, resourceful, and breadth of knowledge becomes particularly salient when considering the emerging work force; the top ten in-demand jobs projected for 2010 did not exist in 2004 (Darling-Hammond, 2010). The new mission of design schools, therefore, must be "to prepare students to work at jobs that do not yet exist, creating ideas and solutions for products and problems that have not yet been identified, using technologies that have not yet been invented" (Darling-Hammond, 2010, p. 2). The advantage will go to those who are able to understand both the problem and increasingly complex contexts of the problem (Van Zandt, 2011). 


\section{The "emerging adult" and american higher education}

To contextualize the need for advanced pedagogical training for faculty in fashion design higher education, it is necessary to understand the undergraduate student demographic. What common attributes are shared among college students? How are they evolving? How will understanding these unique attributes improve fashion design pedagogy and teaching? Gaining an awareness of the undergraduate student demographic will inform faculty, program directors, and institutions how to best evolve and deliver fashion design education.

Despite the fact that the period of "emerging adulthood" has become normative in American society, it wasn't until 2003 that the first scholarly conference was held to discuss the age group (Arnett, 2004). Consequently, studies of college students have been relatively scarce (Arnett, 2000b). In lieu of scholarly research, depictions of this age range have been prevalent in works of fiction and journalistic accounts that frequently depict young people in their 20s as pessimistic and uncertain as they approach adulthood. (Arnett, 2000b)

Following the adolescent population that is typically defined between 10 to 18 years old, "emerging adults" precede full adulthood and range between 18 to 25 years old (Arnett, 2004). While an age range provides one form of demographic demarcation, emotional attributes further contextualize the population's attributes. College students express the true mark of transition into adulthood is more intangible and psychological; these marks include accepting responsibilities for one's actions, making independent decisions, and becoming financially independent (Arnett, 2003). Thus, most college students express they are in the process of attaining these adult attributes.

For many American college students, moving away from home and residing in college dormitories provide a gradual acquisition of these traits that will then be strengthened upon entering adulthood and the professional world. During these formative years, most students begin to investigate and formalize their decisions for a future career through elected coursework, mentorship, and other informative means. However, unlike the European system where students are tracked in earlier levels and typically enter universities with pre-selected majors and career goals, the American undergraduate experience is largely considered to be a time to figure out what one wants to. Professor and author J.J. Arnett (2000a) states:

Emerging adulthood is a time of life when many different directions remain possible, when little about the future has been decided for certain, when the scope of independent exploration of life's possibilities is greater for most people than it will be at any other period of the life course. (p. 469)

It is only during emerging adulthood that life is almost entirely self-focused and decisions can be largely self-directed (Arnett, 2004). This independence and level of self-exploration is in marked contrast to adolescence and adulthood. Adolescents are monitored by parents and typically live by mandates and a prescribed lifestyle. At the onset of adulthood by age 30, most Americans (75\%) have married and have at least one child, thereby bringing new responsibilities and requirements (Arnett, 2004, p. 13). Personal reflection and 
investigation is critical during emerging adulthood since most men and women use this period to create the foundation for their life-long decisions.

In today's professional landscape, this high degree of self-focus is compounded due to the options and possibilities available. Unlike during their parents' generation where gender, socio-economic status, the relative lack of globalization, and the quantity of professional pathways often prescribed a stricter path from adolescence into adulthood, today's college students faces a far different landscape. For example, from 1976 to 2006 the number of women entering college after high school doubled (Arnett, 2010). This new population of female graduates had a profound impact on the future workforce and increased professional opportunities for future generations.

The emerging adult's focus on exploration and experimentation creates a period of great instability. Arnett (2004) states:

Most know they are to have a plan, or some idea of the route they will be taking from adolescence to adulthood. However, the 'plan' is almost always subject to change through changes in college majors and minors, situations that may alter their studies, realizations they need additional schooling, romantic relationships that sway them in different directions, etc. (p. 11)

For most emerging adults, it takes five to six years to obtain a four-year degree due to changing majors, discovering identity, and electing more coursework to compete in the professional marketplace (Arnett, 2004). This has fostered a growing interest among undergraduate students in entering double majors and double degree programs. Institutions are also considering adopting five-year degree programs to meet students' interests and educate them more fully for the increasingly competitive design professions (CFDA, 2011). The exploration and search for one's identity continues after graduation. Upon entering their chosen profession, the average American "holds seven to eight jobs between the ages of 18 and 30, and one in four young workers has more than ten different jobs during this period (Arnett, 2004, p. 146). The period of forming one's identity for today's young adults is a winding road.

The increasingly complex search for identity, abundant options made available to today's generation, and the students' extended studies in undergraduate programs contribute to a dire need for well structured mentorship. In the United States, there is little assistance in facilitating graduates' school-to-work transition due to the lack of adequate guidance; the overwhelming amount of choices young adults face are not being properly supported with directions on how to sort through them (Arnett, 2004). This lack of mentorship leads many emerging adults to experience a "quarter-life crisis" as they change college majors to discover what they want to do while attempting to form an identity.

Low graduation rates further suggest the inadequate guidance offered to pre-college and college students. Although $60 \%$ of American high school graduates enter college, only half of these are well enough prepared educationally (Darling-Hammond, 2010). As a result, about $35 \%$ of an age cohort obtains a college degree, as compared to about $50 \%$ in European counties, and over $60 \%$ in South Korea (Darling-Hammond, 2010). Over the past decade, the U.S. has fallen from the leader to 12 th place in the ratio of 
young people with the equivalent of a bachelor's degree, well behind Russia, Canada, and Japan (Reynolds-Lewis, 2010). The benefits of offering students mentorship can be seen at Virginia Commonwealth University (VCU). The school centralized advising to help incoming freshman with the transition from high school. The initiative led to an $85.3 \%$ student retention rate, up from $80 \%$ just five years earlier (Reynolds-Lewis, 2010). While the costs of hiring additional staff to implement such a program can be high, the initiative pays for itself in tuition from the students who otherwise would have dropped out (Reynolds-Lewis, 2010).

The implications of these trends are also important for national economics. A recent Organisation for Economic Co-operation and Development (OECD) report found that for every year the average schooling level of the population is raised, there is a corresponding increase of $3.7 \%$ in long term economic growth (OECD, 2005). Furthermore, for some students the extended time in an undergraduate program due to changing majors and/or taking additional coursework presents significant financial burden. The cost of college has risen $1,128 \%$ since 1978 , leaving the average 2013 college graduate with $\$ 35,200$ in total debt (Jamrisko \& Kolet, 2012; Ellis, 2013). For many students, this financial burden proves too great to continue their studies and they exit the program and institution without a degree. The need to improve the quality of American higher education system is further suggested by the influx of international students attending U.S. doctoral programs. In The Flat World and Education: How America's Commitment to Equity Will Determine Our Future (2010), author Linda Darling-Hammond cites a National Science Foundation report that states that the pipeline into U.S. Ph.D. programs is now dominated by graduates of Chinese universities (National Science Foundation, 2008). She states:

In 2006, for the first time ever, the top producers of students coming into US doctoral programs were Tsinghua and Beijing universities, with the University of California at Berkeley coming in third. The two Chinese universities nearly quadrupled the number of students they sent to U.S. doctoral programs over the course of a decade. (p. 17)

The competitive field is not relegated to academia alone. For U.S. undergraduate fashion design education, new and increasingly competitive international programs are presenting an unprecedented challenge for the U.S. In Asia, the sum total of design schools in South Korea, Japan, and Singapore was zero, yet today there are more than twenty three schools among them (Postrel, 2003). Many countries such as these are teaching students corecompetencies such as problem solving, design for manufacturability, rapid prototyping, and computer visualization with excellent results. For example, Beijing Institute of Fashion Technology (BIFT) is one such leader; in the past 5 years, over 800 international awards have been garnered by final year student (Arts of Fashion Symposium, 2011). These ambitious countries -many of whom were once focused almost exclusively on garment production rather than "high" design- seek to train the future generations to become leading international designers who have access to local production facilities. With such strong infrastructures and expansions of undergraduate and graduate programs, these nations could marginalize U.S. fashion design programs within a matter of years. (Rothstein, 2005) 


\section{Faculty's pedagogical preparation in the pre-college sector: positive impact in three nations}

The hiring of faculty in American fashion design programs is typically determined by the applicant's undergraduate and/or graduate education, and professional experience. The majority of these tertiary education programs - unlike primary and secondary education- place minimal (if any) requirement on the applicant's pedagogical training; the faculty's professional expertise and knowledge of course content largely informs the hiring decision. However, owing to the increasing factors outlined, it is incumbent upon fashion design higher education to prioritize and provide pedagogy support for faculty if students and the academy are to succeed.

The absence of pedagogical preparation in design higher education is in stark contrast to the pre-college levels, particularly in those nations that have remarkable student rankings. By examining these nations' methodologies for preparing and supporting their faculty in the pre-college levels, U.S. fashion design education will be better informed and prepared for the future academic direction. How have these nations achieved such high levels of student success? How are faculty prepared and supported through pedagogical training? What training frameworks used by the pre-college sector can be adopted by U.S. fashion design higher education?

\section{Historical context}

According to Darling-Hammond (2010), most students today are in an educational system designed at the turn of the 20th century, and based on the factory model pioneered by Henry Ford. Like a factory's assembly line, students move from classroom to classroom, subject to subject, without connecting knowledge between courses. Faculty are unable to track their students' personal development in the advanced levels, thus contributing to the highly prescribed and homogenized academic experience. By the 1950s, technology allowed tests to be performed through multiple-choice that could be scored by machines, without the teacher's involvement or by engaging with students who could define and contextualize their ideas (Darling-Hammond, 2010). However, as research in Education has grown, it's become clear that such depersonalized teaching and learning environments are detrimental to students, particularly for those whose learning styles may differ from the majority. Howard Gardner's seminal text Frames of Mind: The Theory of Multiple Intelligences (1983) sheds a particularly well focused light on academia's need to understand differentiated learning styles and forms of intelligence if all students are to succeed. Globally, schools are evolving these outdated systems and replacing them with models that are highly responsive to students' unique learning styles. Darling-Hammond (2010) states many top-performing nations are:

...revising their curriculum, instruction, and assessment to support the more complex knowledge and skills needed in the 21st century. Starting in the 1980s, for example, Finland dismantled the rigid tracking system 
that had allocated differential access to knowledge to its young people and eliminated the state-mandated testing system that was used for this purpose, replacing them with highly trained teachers and curriculum and assessments focused on problem solving, creativity, independent learning, and student reflection. (p. 5)

These changes have propelled South Korea, Singapore, and Finland to the top of international rankings while the U.S. is falling far behind and standing still in school improvements, as evidenced by various ranking systems (Darling-Hammond, 2010). The Program in International Student Assessment (PISA) requires more advanced analysis and knowledge use than most U.S. tests, going beyond the testing of specific facts and what students can do with what they have learned (Darling-Hammond, 2010). PISA assess students' ability to apply what they've learned to new problems, and the ability to transfer knowledge through critical and contextual scenarios. In 2012, the U.S. ranked 26th out of 34 countries in the Organization for Economic Cooperation and Development (OECD) in mathematics, and close to the OECD "average" in reading and science. (OECD, 2012). Meanwhile, China (Shanghai) "performed in the equivalent of over two years of formal schooling ahead of those observed in Massachusetts, itself a strong-performing U.S. state (OECD, 2012).

In the space of just one generation, South Korea, Singapore, and Finland have risen from among the lowest rankings to among the highest in the world. With such rapid and remarkable results, what commonalities do these nations share in their education system? What methods of pedagogy preparation and teacher support contribute to these successful rankings? How can fashion design higher education benefit from these methods?

\section{Case studies: three leading nations}

\section{Introduction}

With exceptions, the U.S. has failed to maintain focused investments in developing a well prepared and stable teaching force (Darling-Hammond, 2010). The need for developing prepared faculty is particularly salient when considering the cost of teacher attrition: A study of the state of Texas -which has higher than average annual attrition ratesestimated that in 2000, teacher losses cost the state between $\$ 329$ million and $\$ 2.1$ billion (Benner, 2000). Although this study focused on the pre-college sector, the costs associate with hiring and replacing faculty in higher-education can be avoided in part by focusing on developing well prepared and stable faculty.

Inadequate teacher preparation also contributes to high turnover rates and the teacher's sense of effectiveness. Although many new teachers believe they do not need much specialized preparation before entering a classroom to teach, most learn quickly that teaching is far more difficult than initially thought. New faculty either desperately seek out additional training, develop a teaching style that "dumbs down" the curriculum so that it 
is more easily managed, or leave the profession altogether in despair (Darling-Hammond, 2010). Teachers with stronger initial preparation typically stay in teaching significantly longer, as do those who receive high quality mentoring in their first year on the job. This preparation and subsequent retention develops a closer and more supportive community, greater institutional memory, and faculty who are more deeply invested in their school's success.

In the longer-term, experienced faculty are able to strengthen their teaching skills, gain a more sensitive understanding of student development, discover effective classroom management techniques, and improve their curriculum each year. Experienced, committed, and supported faculty may also serve as mentors to junior faculty, thereby contributing towards students' success; while the U.S. has an estimated student retention rate of fifteen to twenty percent annually, which is on par with Haiti and Sierra Leone, Asian nations typically hold back fewer than one percent of students each year or bar grade retention entirely. (Smith \& Shepard, 1987)

\section{Case study 1: South Korea}

The Korean proverb “Don't even step in the shadow of a teacher" reflects the nation's deep respect for the profession. Teachers are so respected in Korea that they rank with priests in a recent opinion poll as the most trusted members of society (Darling-Hammond, 2010). This deep cultural respect is also evidenced by the high salaries teachers earn; salaries are only slightly lower than those of Korean doctors and yield purchasing power within the local economy nearly 250\% higher than US teachers (Kang \& Hong, 2008). This level of respect makes working conditions and the profession highly desirable amongst Koreans, thus leading many to pursue the profession through university studies. In total, eleven public and two private universities produce teachers. Regardless of the institution, all students receive a standard, required program of studies in specific content and pedagogy. In order to graduate, all students must successfully complete a two-part exam that include essay and short answer question, interviews, and classroom performance. Obtaining a teaching post once graduated is highly competitive: typically, only one in twenty applicants receive jobs in Seoul. (Darling-Hammond, 2010)

Once hired, teachers receive extensive preparation to ensure they become highly skilled educators. The new faculty members receive a six-month introduction program that is managed by senior administration and teacher mentors who provide classroom guidance and supervision. During this period, courses are offered and subsidized by the ministry and by local offices of education. The faculty member's professional development is both expected and supported in the following years. Following the fourth year of teaching, teachers are required to take ninety hours of professional development courses every three years; after three years of teaching, faculty may enroll in a five-week professional development certificate program and thus receive salary increase and eligibility for promotion. (Darling-Hammond, 2010)

The nation's commitment to providing faculty with professional development is further reflected in their teaching schedules. During the week, teachers spend $35 \%$ of their time 
teaching pupils with the rest of the time devoted to professional development, planning, and grading (Darling-Hammond, 2010). This is less than half the ratio of US schools where instruction comprises about $80 \%$, leaving little time for professional development (Darling-Hammond, 2010). The curriculum is centered on Dewey's philosophies by blending concerns for the development of the whole child (intellectual, moral, physical, emotional) with thoughtful and skillful teaching.

The impact these highly skilled teachers make on their students is suggested in part by secondary school graduates who go on to earn a bachelor's degree: Over $60 \%$ of South Koreans obtain a college degree, compared to the $35 \%$ of Americans, and in one generation the nation moved from educating less than one-quarter of its citizens through high school to one that now ranks third in college-educated adults. (Darling-Hammond, 2010)

\section{Case study 2: Singapore}

Singapore experienced a remarkably quick transformation in its education system and subsequent international student rankings. Beginning in the 1970s, Singapore evolved into a global economic powerhouse through an educational system centered on developing strong, highly qualified teachers. The evolution became particularly noteworthy under Singapore's second Prime Minister Goh Chok Tong, whose national initiative in 1997 emphasized "thinking school, learning nation" in a nation whose people are considered "it's only natural resource and its education system as the primary resource developer". (Darling-Hammond, 2010, p. 182)

In order to build and sustain this resource of human intellect, Singapore reformed the nation's curriculum, assessment methods, and teaching through the development of a critical culture within all schools. Faculty were engaged by being asked "to conduct action research on their teaching and to continually revise their teaching strategies in response to what they learned" (Darling-Hammond, 2010, p. 182). This new research-based approach to education included the reduction of content in the national syllabi by ten to thirty percent, thereby allowing for more project work and independent learning. Prime Minister Lee Hsien Loong urged educators to "teach less to our students so that they will learn more" during his speech at Singapore's 2004 National Day Rally, thus underscoring the need to focus on quality rather than quantity.

Singapore's commitment to education and students' academic excellence is exemplified by the nation's heavy investments in teacher recruitment, training, and mentorship. To obtain the very best teachers, the top one-third of graduating high school students are recruited into fully paid undergraduate teacher education programs. Upon graduation and entrance into the field, they earn as much -or more- than beginning engineers, accountants, lawyers, and doctors (Darling-Hammond, 2010). Novice teachers are not left to "sink-or-swim"; senior-level teachers, trained by the National Institute as mentors, are given release time to work with entering faculty cohorts. During this structured first year, beginning teachers also attend courses in classroom management, counseling, reflective practices, and assessment offered by the National Institute and the ministry. Following this year, the government pays for 100 hours of professional development each year for 
all teachers, in addition to the 20 hours they work with other teachers and observe classes to perfect their pedagogy (Darling-Hammond, 2010). Teacher-led workshops encourage the sharing of ideas, support professional development, advance research to further the faculty's pedagogy, and create a highly collegial work environment.

The results of these supportive structures are staggering. For example, fourth grade students' scores on the 2011 Trends in International Mathematics and Science Study (TIMSS) test placed Singapore alongside the other top performing nations of South Korea and Hong Kong SAR (TIMSS, 2011). This is even more remarkable when considering that "fewer than half of Singapore's students routinely speak English, the language of the test, at home". (Darling-Hammond, 2010)

\section{Case study 3: Finland}

Like South Korea and Singapore, Finland implemented significant education reforms in a relatively short time span to prepare its population for the advancing knowledge economy. The country's agrarian society was quickly transformed into a knowledge-based society that ranked the most competitive in the world by the World Economic Fund in four out of five years from 2001 to 2005 (Darling-Hammond, 2010). This accomplishment is particularly remarkable given Finland's recovery from a banking crisis and near economic collapse in the early 1990s.

The new reforms and academic direction was made possible though the Finnish government that prioritized teacher training. As Darling-Hammond (2010) notes:

Leaders in Finland attribute these gains to their intensive investments in teacher education -all teachers receive 2 or 3 years of high quality graduate level preparation completely at state expense- plus a major overhaul of the curriculum and assessment system design do ensure access to a "thinking curriculum" for all students. (p. 167)

Finns understood that education was "necessary and a potential investment -not just expenditure-in helping to develop innovation and adopting more innovation throughout the economy" (Sahlberg, 2010, p. 107). Pasi Sahlberg, currently Visiting Professor at The Harvard Graduate School of Education and former Counsellor of Education for The Finnish Ministry of Education, continues,"without excellent teachers and a modern teacher education system, Finland's current international educational achievement would have been impossible" (Sahlberg, 2010, p. 71). The teaching profession, then, is one that is highly revered in Finland and viewed as a key player in building the nation's welfare.

Teaching is consistently rated as one of the most admired professions, ahead of doctors, lawyers, and architects, often thought to be ideal professions (Liiten, 2004; Sahlberg, 2010). It is no surprise then, that interest in the profession is very high among university applicants; approximately $25 \%$ of Finnish high school students express interest in becoming teachers, according to Sahlberg (Anderson, 2011). Gaining entrance into teaching preparation programs is highly competitive and only the best and most committed are accepted. 
For example, in 2010, 6,600 applicants competed for 660 student positions for Finnish primary school teacher education programs in Finnish universities (Sahlberg, 2010). At the University of Helsinki alone, 2,400 people competed for 120 fully-subsidized slots in the master's program for schoolteachers in 2010 (Anderson, 2011). The 10\% that are admitted enter a three-year graduate-level program that is entirely free and includes a living stipend (Sahlberg, 2010; Darling-Hammond, 2010). As a result, teaching shortages are virtually unheard of. (Darling-Hammond, 2010)

Programs included both extensive coursework on how to teach -with a strong emphasis on using research based on state-of-the-art-practices- as well as research in learning and teaching (Darling-Hammond, 2010). Teachers are trained in research methods so they can "contribute to an increase of the problem solving capacity of the education system" (Buchberger \& Buchberger, 2004, p. 16). This emphasis on scholarly research in teacher education is expressed by Hannele Niemi, Professor of Education at the University of Helsinki. He states (Darling-Hammond, 2010) that research based education has the following three key principles:

- Teachers need a deep knowledge of the most recent advances of research in the subjects they teach. In addition, they need to be familiar with the research on how something can be taught and learned.

- Teachers must adopt a research-oriented attitude toward their work. This means learning to take an analytical and open-minded approaches to their work, drawing conclusions for the development of education based on different sources of evidence coming from the recent research as well as their own critical and professional observations and experiences.

- Teacher education in itself should also be an object of study and research. (Hannele Niemi)

Niemi further asserts that the most significant change that created such success in the Finnish education system was "the requirement that all teachers must hold a[n] academic master's degree in education or in the subject they teach in school. It launched a development chain that elevated teachers [who] are able to understand teaching holistically and improve their own work continuously". (Sahlberg, 2010, p. 84)

Graduates enter a highly supportive school system. At least one afternoon each week is devoted to collaboratively planning and developing curriculum, with additional time being provided for professional development within the work week. As with many Asian nations, nearly half of the faculty's school time is used to hone practice through schoolbased groups, collective planning, and parental involvement. The work environment also allows for tremendous professional autonomy, prestige, and trust, which explains why so many young Finns regard teaching as a most admired career (Sahlberg, 2010). In fact, "the working conditions and moral professional environment are what count as young Finns decide whether they will pursue a teaching career or seek work in another field". (Sahlberg, 2010, p. 77)

In addition to a highly desirable work environment, faculty are provided with substantial professional development; approximately \$30 million U.S. dollars of the Finnish state 
budget are allocated for such services as university courses and in-service training (Sahlberg, 2010). By 2016, The Ministry of Education, in collaboration with Finnish municipalities, plans to double public funding for teacher professional development (Sahlberg, 2010). This is remarkable when compared to the $\$ 5$ million the U.S. allocates for student assessment and testing. (Sahlberg, 2010)

This emphasis on professional development and research in teacher education and the teaching practice fosters a highly advanced form of pedagogy. In classroom contexts, teachers and students engage in problem solving groups that address planning, action, and reflection/evaluation that is also emphasized in the teaching preparation programs. Inquiry through research, rather than rote memorization and the "banking" of knowledge, is the focus of learning. This inquiry-focused learning produces students who:

...determine their own weekly targets with their teachers in specific subject areas and choose the tasks they will work on at their own pace. Students are likely to be rotating through workshops or gathering information, asking questions of their teacher, and working with other students in small groups (...). The cultivation of independence and active learning allows students to develop metacognitive skills that help them to fame, tackle, and solve problems; evaluate and improve their own work; and guide their learning processes in productive ways. (Darling-Hammond, 2010, p. 170)

Following their assignments, students are assessed largely through feedback in narrative format that describes the individual student's learning progress and areas for growth (Sahlberg, 2007). This intensive and highly personalized focus on student learning is in marked contrast to those nations that employ impersonal standardized tests and "blanketed" pedagogy across each course level, shuffling students to new faculty each year or term. In fact, standardized testing is optional in Finland (with the exception of the test high school seniors take prior to graduation) and teachers may have the same students for five years in a row, thus creating close teacher-student academic guidance. (Hancock, 2011) These initiatives have propelled students' achievement to the top international rankings. Approximately 93\% of Finns complete upper academic or vocational secondary school, and 66\% enroll in universities, the highest rate in the European Union (Hancock, 2011). Comparatively, $72.2 \%$ of Americans completed high school in 2012 (U.S. Department of Education, 2013). The Finnish cultural emphasis and value for education is further evidenced by the adult population of which over $50 \%$ participates in adult education programs, and the $98 \%$ of education costs (at all levels) that are covered by the government rather than private sources. (Darling-Hammond, 2010)

\section{Summary and conclusion}

The seismic changes occurring in U.S. fashion design education will require programs to abandon their long-held "sink or swim" approach when placing faculty in the classroom. If faculty are to succeed in the new academic landscape, programs must provide them with 
advanced pedagogical methodologies and professional development. By addressing the importance of teacher training in art and design higher education, the institution, faculty, students, graduates, and the wider industry will flourish.

The future of fashion design education is being radically altered due to the accelerated industry, evolving knowledge-based economy, and subsequent shift in the designer's role. Curricula is responding by emphasizing theory, inter -and cross- disciplinary studies, innovative design processes, and student collaborations. These changes are requiring practice-based faculty to adopt teaching methodologies that have remained largely unchanged since their program's inception. Furthermore, design higher education must acknowledge the differentiated skills required to design and to teach. Teacher training will greatly improve faculty retention, academic community, students' and graduates' success, and future industry practices. To create this change, further research into successful teacher preparation programs must occur. By doing so, program directors and faculty will gain insights for developing their own unique programs.

The three nations profiled in this paper are particularly unique due to their successes achieved in a relatively short time span. These nations share commonalities that are critical for faculty and student success: teaching is viewed as a research-based practice; faculty receive substantial support for ongoing professional development; large portions of the faculty's work week are spent developing and evolving curriculum; faculty participate in mentorship and peer support groups; pedagogy addresses students' differentiated learning styles and provides student assessment through narrative feedback, rather than a blanked, "one size fits all" teaching style; and the holistic development of the student (intellectual and emotional) is emphasized. Although these case studies focus on secondary and primary education, they demonstrate successful outcomes when faculty acquire advanced pedagogy, thereby allowing students, programs, and national industry to succeed.

\section{References}

Agid. S. (2008, fall) Re: Imagining Parsons - How Parsons' new academic structure is shaping design education in the 21st century. Re:D , 26(2), 11-15

Anderson, J. (2011, December 12). From Finland, an intriguing school-reform model. The New York Times. Retrieved from http://www.nytimes.com/2011/12/13/education/fromfinland-an-intriguing-school-reform-model.html?pagewanted=all\&_r $=0$

Arnett, J.J. (2000a). Emerging adulthood: A theory of development from the late teens through the twenties. American Psychologist, 55 (5), 469-480.

Arnett, J. J. (2000b). High hopes in a grim world: Emerging adults' view of their futures and "generation x". Youth and Society, Vol 13, no 3, March 2000. Sage Publications. (Pg 267-286)

Arnett, J. J. (2003). Conceptions of the transition to adulthood among emerging adults in American ethnic groups. New Directions for Child and Adolescent Development, 100 (Summer 2003), 63-75.

Arnett, J. J. (2004) Emerging adulthood: The winding road from the late teens through the twenties. New York: Oxford University Press. 
Arnett, J. J. (2010). Oh, grow up! Generational grumbling and the new life stage of emerging adulthood - commentary on Trzeniewski \& Donnellan. Perspectives on Psychological Science, 5(I), 89-92.

Bard, B. (1974, November). The fashion world's Harvard.. Change, (6) 9, 52-53.

Benner, A.D. (2000). The cost of teacher turnover. Austin: Texas Center for Educational Research.

Brown, T. (2009). Change by design: How design thinking transforms organizations and inspires innovation. New York: HarperCollins.

Buchberger, F. \& Buchberger, I. (2004). Problem-solving capacity of a teacher education system as a condition of success? An analysis of the "Finnish case". In F. Buchberger \& S. Berghammer (Eds.), Education Policy Analysis in a Comparative Perspective (pp. 222-237). Linz, Austria: Trauner.

Clark, H. (1991). Design history and British design education. An appraisal. Elisava: Themes de Disseny. Retrieved from http://tdd.elisava.net/coleccion/6/clark-en

Clifford, S. (2011, September 13). Demand at Target for fashion line crashes web site. The New York Times. Retrieved from http://www.nytimes.com/2011/09/14/business/demandat-target-for-fashion-line-crashes-web-site.html

Crane, F. (1951). The artist in each of us. New York: Pantheon Books.

Darling-Hammond, L. (2010). The flat world and education: How America's commitment to equity will determine our future. New York: Teacher College Press.

Elfand, A. (1990). The history of art education: Intellectual and social currents in teaching the visual arts. New York: Teachers College Press.

Ellis, B. (2013, May 17). Class of 2013 grads average \$35,200 in total debt. CNN Money. Retrieved from http://money.cnn.com/2013/05/17/pf/college/student-debt/

Fry, A., Faerm, S., \& Arakji, R. (2013). Achieving the new graduate dream: building sustainable business success at a small scale. Cuaderno, 48, pp. 153-175. Buenos Aires: Universidad de Palermo.

Friedman, K. (2003). Design education in the university: A philosophical \& socio-economic inquiry. Design Philosophy Papers, (1)5. Retrieved from 2014.researchbank.swinburne. edu.au/vital/access/services/Download/swin:13686/SOURCE1

Friedman, T. (2005). The world is flat. New York: Farrar, Straus and Giroux.

Gardner, H. (1983). Frames of mind: The theory of multiple intelligences. New York: Basic Books.

Hancock, L. (September 2011). Why are Finland's schools successful? The country's achievements in education have other nations, especially the United States, doing their homework. Smithsonian Magazine. Retrieved from http://www.smithsonianmag.com/ innovation/why-are-finlands-schools-successful-49859555/?page $=2$

Ilyin, N. (2006). Chasing the perfect: Thoughts on modernist design in our time. New York: Litton Educational Publishing Inc.

Jamrisko, M. \& Kolet, I. (2012, August 15). Cost of college degrees in U.S. soars 12 fold: Chart of the day. Bloomberg News. Retrieved from http://www.bloomberg.com/news/2012-0815/cost-of-college-degree-in-u-s-soars-12-fold-chart-of-the-day.html

Jukes, I. \& McCain, T. (2002, June 18). Living on the future edge. British Columbia: InfoSavvy Group andCyster. Retrieved from http://www.oten.info/conferences/jukes/JukesLFE.pdf 
Kang, N.H. \& Hong, M. (2008). Achieving excellence in teacher workforce and equity in learning opportunities in South Korea. Educational Research, 37(4), pp. 200-207.

Leonard, A. (2010). The Story of stuff: How our obsession with stuff is trashing the planet, our communities, and our health -and a vision for change. New York: Free Press.

Liiten, M. (2004). Ykkossuosikki: Opettajan ammattii [Top favorite: Teaching Profession]. Helsingin Sanomat. Retrieved from http://www.hs.fi/artikkeli/Ykk\%C3\%B6ssousikki+o pettajan+ammatti/1076151893860.

Marshall, T. (2009, January). Designing design education. Form, 224. Retrieved from http:// www.icograda.org/education/education/artilces/page2.html

Merchant, K. (2003, June 3). GE Champion's India’s World Class Services, Financial Times, 11.

The Municipal Art Society of New York. (2011, October 14). Fashioning the future: NYC's garment district. Retrieved from http://mas.org/urbanplanning/garment-district/

Muratovski, M. (2010). Design and design research: The conflict between the principles in design education and practices in industry. Design Principles and Practices, (4) 2, 377-386.

National Science Foundation. (2008). Survey of earned doctorates. Arlington, VA.: U.S. Government Printing Office.

Organisation for Economic Cooperation and Development (OECD). (2005). Education at a glance: OECD indicators, 2005. Retrieved from http://www.oecd.org/edu/skills-beyondschool/educationataglance2005-home.htm

Organisation for Economic Cooperation and Development (OECD). (2012). Programme for international student assessment (PISA): Results from PISA 2012. Retrieved from http:// www.oecd.org/pisa/keyfindings/PISA-2012-results-US.pdf

Pecker, D., Schmidt, D., Bernstein, D. Estabrook, K., \& Alden, M. (Producers) \& Keeve, D. (Diretor). (1995). Unzipped [Motion picture]. United States: Hachette Filipacchi Films and Mirmax Films.

Pink, D.H. (2005). A whole new mind: Why right-brainers will rule the future. New York: Riverhead Books.

Pinkerson, D. \& Levin, M. (Producers) \& Levin, M. (Director). (2009). Schmata: Rags to riches to rags [Motion picture]. United States: Home Box Office Documentary Films.

Postrel, V. (2003). The substance of style. New York: HarperCollins Publishers.

Reynolds-Lewis, K. (2010, October 28). High college dropout rate threatens U.S. growth. The Fiscal Times. Retrieved from www.thefiscaltimes.com

Rothstein, P. (2005, May). Rethinking design education in a time of change: Risks and rewards. Innovation, 23-25.

Sahlberg, P. (2007). Educational change in Finland. In A. Hargreaves, M. Fullan, A. Lieberman, \& D. Hopkins (Eds.), International Handbook of Educational Change, 1-28. Dordrect,The Netherlands: Kluwer Academic Publishers.

Sahlber, P. (2010). Finnish Lessons: What can the world learn from educational change in Finland?. New York: Teachers College Press.

Siegel, L. (2011, May 8). Why fast fashion is slow death for the planet. The Guardian, 35.

Smith, M.L. \& Shepard, L.A. (1987). What doesn't work: Explaining policies of retention in the early grades. Phi Delta Kappan, 69(2), 129-134.

Skjold, E. (2008). Fashion research at design schools. Kolding, Denmark: Kolding School of Design. 
Trends in International Mathematics and Science Study (TIMSS). (2011). TIMSS International results in mathematics. Retrieved from http://timss.bc.edu/timss2011/ downloads/T11_IR_M_Chapter1.pdf

The United States Department of Education. (2013). High school graduation rate at highest level in three decades. Retrieved from http://www.ed.gov/blog/2013/01/high-schoolgraduation-rate-at-highest-level-in-three-decades/

Van Zandt, D. (2011). Inaugural address. Retrieved from http://www.newschool.edu/ leadership/president/installation/

Varian, H. \& Lyman, P. (2003). How much information? UC Berkeley School of Information Management \& Systems (SIMS). Retrieved from http://www2.sims.berkeley.edu/research/ projects/how-much-info-2003/printable_report.pdf

Vogue. (2013). Media press kit. [Data file]. Retrieved from http://www.condenast.com/ brands/vogue/media-kit/print/rates

Wax, M. (2010). Out of the Bauhaus and into the Future. (Unpublished master's thesis). Pratt Institute, Brooklyn, New York.

Williams, A., Ostwald, M., Askland, H. (2011). The relationship between creativity and design and its implication for design education. Design Principles and Practice, (5)1, 57-71.

Wolff, L., Rhee, J. (2009, May). Is design the new liberal arts? Re:D (Regarding Design), 26(6), 9-13.

Resumen: Históricamente, las universidades han adoptado un enfoque de "hundirse o nadar" al momento de contratar profesores de arte y diseño. Después de años de experiencia profesional, estos nuevos profesores entran a las aulas sin formación pedagógica mientras se espera que sean exitosos como educadores. Sin embargo, diseñar productos y educar a estudiantes requiere un conjunto de competencias significativamente diferentes. Además, los retos de los docentes aumentan radicalmente debido a los cambios que se producen en la enseñanza del diseño, una generación estudiantil que evoluciona, y un mundo profesional cada vez más volátil para el cual los estudiantes deben estar capacitados. A través del ensayo-error, los nuevos profesores a menudo se basan en métodos de enseñanza anticuados utilizados durante sus propias experiencias de pregrado. Esta falta de preparación de los profesores impacta negativamente en los programas de estudio, en la preparación de los egresados, y en última instancia en nuestras industrias de diseño. En este artículo se discutirá acerca de la necesidad crítica para los futuros docentes de arte y diseño de adquirir y dominar habilidades pedagógicas sólidas si han de educar y formar con éxito a los futuros diseñadores. Este estudio tiene como objetivo concientizar a los educadores de diseño de moda y directores de programas educativos sobre la importancia de brindar apoyo pedagógico a los nuevos profesores con el fin de fortalecer el aprendizaje de los estudiantes.

Palabras clave: educación - pedagogía del diseño - desarrollo estudiantil - enseñanza - diseño de moda - industria de la moda - Parsons - profesores - educación superior. 
Resumo: Historicamente, as universidades adotaram um enfoque de "afundar-se ou nadar" ao momento de contratar professores de arte e design. Depois de anos de experiência profissional, estes novos professores entram às aulas sem formação pedagógica enquanto se espera que tenham sucesso como educadores. Contudo, desenhar produtos e educar aos estudantes requer um conjunto de competências significativamente diferentes. Além, os retos dos professores aumentam radicalmente devido às mudanças que se produzem no ensino do design, uma geração estudantil que evolui, e um mundo profissional cada vez mais volátil para o qual os estudantes devem estar capacitados. Através do ensaio-erro, os novos professores frequentemente se baseiam em métodos de ensino antiquado usados durante suas próprias experiências de pré-grau. Esta falta de preparação dos professores impacta negativamente nos programas de estudo, na preparação dos graduados, e em última instancia em nossas indústrias de design. Neste artigo se discutirá a necessidade crítica para os futuros docentes de arte e design de adquirir e dominar habilidades pedagógicas sólidas se educarão e formarão com êxito aos futuros designers. Este estudo tem como objetivo conscientizar aos educadores de design de moda e diretores de programas educativos sobre a importância de dar apoio pedagógico aos novos professores com o fim de fornecer a aprendizagem dos estudantes.

Palavras chave: educação - pedagogia do design - desenvolvimento estudantil - ensino design de moda - indústria da moda - Parsons - professores - ensino superior. 